\title{
Notice
}

This material (version March 2000) has been accepted by Academic Press for publication in

\section{Brain and Cognition}

Copyright may be transferred without notice, after which this version may no longer be accessible.

Copyright @ Brigitte Stemmer

See also the Poster presented at TENNET, 15-17 June, 2000.

For a more detailed version (including topics not covered here, more practical hints on copyright, and more Web addresses) see the article The silent revolution in electronic publishing and its relevance for the mind and brain sciences (Brigitte Stemmer) in the Cogprints archive.

\section{THE MIND AND BRAIN SCHOLAR AS A HITCH-HIKER IN POST-GUTENBERG GALAXY: PUBLISHING AT 2000 AND BEYOND}

\author{
Brigitte Stemmer*\#, Marianne Corre*, and Yves Joanette* \\ *Centre de Recherche \\ Institut Universitaire de Gériatrie de Montréal, Canada \\ \#Centre de Neuroscience de la Cognition, \\ Université du Quebec à Montréal, Canada
}

\begin{abstract}
Address correspondence and reprint requests to
Brigitte Stemmer

E-mail: stemmer@magellan.umontreal.ca

Acknowledgment:

Preparation of this paper was supported by the Centre de Neuroscience de la Cognition,

Université du Quebec à Montréal (UQAM), Canada
\end{abstract}




\section{Stemmer et al., Electronic publishing}

\section{$\underline{\text { Abstract }}$}

Electronic journal (e-journal) publishing has started to change the ways we think about publishing. However, many scholars and scientists in the mind and brain sciences are still ignorant of the new possibilities and on-going debates. This paper will provide a summary of the issues involved, give an update of the current discussion, and supply practical information on issues related to e- journal publishing and self-archiving relevant for the mind and brain sciences. Issues such as differences between traditional and e-journal publishing, open archive initiatives, worldwide conventions, quality control, costs involved in e-journal publishing, and copyright questions will be addressed. Practical hints on how to self-archive, how to submit to the e-journal Psycoloquy, how to create an open research archive, and where to find information relevant to epublishing will be supplied. 


\section{Stemmer et al., Electronic publishing}

\section{Introduction}

Consider the following scenarios: You need a paper quickly but still cannot access that particular article on the Internet because you have not subscribed to that particular journal, or because it is too expensive to download, or simply because you cannot find the article online. And what about your own papers - the ones you submitted a year ago but still haven't been published? Or the recently published article where you had to pay outrageous charges for some color images or 'complex' tables when it was so easy to have all these attractive and useful images on the screen? Not to mention the extra page charges you had to pay. In addition, you had to cut the size of the paper and omit important data despite it taking so little harddisk space. And what about the experimental design? Wouldn't it have been so much easier to simply show in a video clip how it worked?

All this and more you are already able to and will do in the very near future. Although electronic journal (e-journal) publishing has started to change the ways we think about publishing, many scholars and scientists are still ignorant of the new possibilities and on-going debates. It is thus the goal of this contribution to provide a summary of the issues involved, give an update of the current discussion, and supply practical information on issues related to electronic journal publishing and self-archiving relevant for the mind and brain sciences.

\section{Traditional journal publishing, e-journal publishing, and the open archive initiative}

A fundamental difference between traditional journal publishing and e-journal publishing lies in the interests and goals of the parties involved. While the scholar and scientist's main interest is the fast communication of knowledge and recognition through publication, the publisher seeks financial gains through the exclusive distribution of such scientific information. For the first time in 200 years, through the advancement of information technology, the dependence of the scientist 


\section{Stemmer et al., Electronic publishing}

on the publisher to disseminate his knowledge is dissolving. Through the Internet, scientific information dissemination is cheap, fast, universally accessible, and can be presented in interactive and multimedia form. Whereas many paper publishers now offer free automatic content alert and abstract access, access to full articles on the Internet is usually charged through subscriptions, site licenses and pay-per-view plans, only few offer free of charge full text access (see Table 1). Scientists have started to take publishing in their own hands and have created free of charge ejournals such as Psycoloquy, a refereed international interdisciplinary journal sponsored by the American Psychological Association which covers psychology, cognitive science, neuroscience, behavioral biology, AI, linguistics and philosophy. In addition, open research archives have been established such as CogPrints where authors can self-archive their papers free of charge and thus make them available to the scientific community worldwide. CogPrints was launched by Stevan Harnad and specifically archives papers related to the mind and brain sciences.

However, just as in paper publishing, quality of content and form is a concern of scientists also in e-publishing. In addition, due to the new medium, questions concerning short- and long-term compatibility of the material published and between the various open research archives as well as long-term storing and accessibility, form of citation, indexing and addressing arise.

$* * * * * * * * * * * * * * * * * * * * * * * * *$

INSERT TABLE 1 ABOUT HERE

$* * * * * * * * * * * * * * * * * * * * * * * * *$ 


\section{Stemmer et al., Electronic publishing}

\section{Worldwide conventions and quality control}

To secure worldwide interoperability between open research archives first standards were agreed upon at Santa Fe in October 1999 <www.openarchives.org/ups1-press.htm>. Universities, institutions, departments, and individuals worldwide can now launch their own open archives and use software (free of charge) abiding to the Santa Fe standards (available from CogPrints archive <http://cogprints.soton.ac.uk/>; see also the step by step instructions for the open archives at <http://www.openarchives.org/sfc/sfc.htm>). An NIH-operated site for electronic distribution of life sciences research reports called PubMed Central archives, organizes and distributes peer-and non-peer-reviewed reports from journals since January 2000.

What about the quality of the papers? Opinions diverge widely. Some argue that everything should be published as the readers can make their own judgments (unfiltered admission to archives), others view the electronic peer commentary model, i.e. any comment a reader wants to make to an on-line contribution, a sufficient filter (Sekiwaka, 1998, september98-Forum archive). At the other extreme voices have been raised that object to peer-reviewed and non-peer-reviewed online publishing per se on grounds of a possible public health risk when, for example, results of new clinical studies are published without the guidance of an editorial or peer comment (Relman, 1999). Harnad (1998b), a strong advocate for free online publishing, points out that for unrefereed online publication of clinical trials cautionary measures can and should be agreed upon. However, he generally argues for maintaining a peer-review model similar to the procedures involved in traditional publishing, the difference being that through the electronic medium a faster and more efficient system could be organized. In addition, just as in traditional publishing, the editor's role in making the final decision for publication can also hold for e-journal publishing (Ransdell, 1999). 


\section{Stemmer et al., Electronic publishing}

In summary, compared to traditional paper publishing, e-journal publishing serves the scholar and scientist's goal better, it is faster and more efficient, necessary international standards have already and are continuously worked out, and the quality of the papers can be controlled. The next questions that arise are: Who will be paying for this all? And what about copyright issues? Can scientists simply self-archive their submitted or already published article?

\section{What are the costs involved and who will pay for it?}

Whereas paper publishers claim that savings for e-publishing would not be more than $30 \%$, others have convincingly shown that savings of $70 \%$ are real (Bot, Burgemeester, \& Roes, 1998; Harnad, 1998a; Odlyzki; 1998, Walker, 1998). Long-term experience with the Los Alamos National Laboratory (LANL) Physics Archive has shown that the costs of establishing and maintaining the archive itself are negligible. What needs to be covered after self-archiving has been established, is quality-control and certification (peer review and editing). Library and institutional paper journal subscriptions (within 20 years libraries have faced a price increase for journal subscription from $39 \$$ to $284 \$$ ) will ultimately be canceled and it has been suggested that these savings would be sufficient to pay for the remaining e-publishing services (Harnad, 1998a,b).

\section{Who owns the copyright?}

Before an accepted manuscript is published, authors usually have to sign a copyright agreement that transfers the copyright to the publishers and denies the authors any right to freely distribute their intellectual property, while, at the same time, the publishers, who now "own" this intellectual property, make considerable financial profits. Strong objections against this practice have been raised (for a summary see the discussion in the September98-Forum archives; Bennett, 


\section{Stemmer et al., Electronic publishing}

1999; Harnad, 1999b) and alternative models have been suggested. The Association of Learned and Professional Society Publishers (ALPSP) <www.alpsp.org.uk> has drafted a model 'Grant of Licence" form for journal articles that tries to accommodate both, the publishers' commercial and the scientists' interests <www.alpsp.org.uk/grantli.pdf>. With the majority of journals the copyright situation remains vague for online self-archiving and posting but some publishers are currently changing their policies and it is expected that others will follow (see Table 1). There is no copyright problem for archiving pre-refereeing drafts that have been submitted. Note, however, that some journals (such as 'Science') view pre-print posting as already published material. For accepted articles, where the publishers explicitly forbid self-archiving, there are procedures that will still allow self-archiving (see information in Harnad, 1999a and discussion in the September98-Forum archives). (For general questions concerning copyright see $<\mathrm{http}: / /$ cogprints.soton.ac.uk/help/copyright.html>, <http://web.mit.edu/copyright> and the link to the digital millennium copyright act).

\section{Practical hints for e-journal publishing and self-archiving}

How to self-archive. Go to CogPrints <http://cogprints.soton.ac.uk> and follow the step-by-stepprocedures. It is advisable to convert your article to HTML or postscript format (check out the CogPrints help on this issue). Alternatively, check out whether your university, institution, library, or department is certified to submit material to NIH's PubMed Central:

<http://www.nih.gov/about/director/pubmedcentral/pubmedcentral.htm>.

Want to submit an article to Psycoloquy? Information and help can be found at $<$ http://www.princeton.edu/ harnad/psyc.html >. 


\section{Stemmer et al., Electronic publishing}

You want to create your own open research archive? Go to <http://cogprints.soton.ac.uk> and follow the links to download the free software which is currently being redesigned to serve as a global and generic Santa-Fe-compliant institutional open archive for the cognitive sciences (and all other disciplines). Go to <http://www.openarchives.org > where you will find the core document of the Santa Fe Convention providing a step by step approach for making your e-print archive or your service comply with the Santa Fe Convention.

Looking for journals or newsletters available on the internet? Check out <http://gort.ucsd.edu/newjour/> or HighWirePress which maintains a list of journals that offer free downloads for back issues, free trial periods and free sites <http://www.highwire.org/>.

Looking for information on all aspects of e-publishing? Go to the American Scientist September98-Forum archives :

<http://amsci-forum.amsci.org/archives/september98-forum.html>.

The archives can be searched by author name, posting date or topic.

\section{$\underline{\text { 7. Conclusions }}$}

E-journal publishing will replace traditional paper journal publishing and will be accessible free of charge to anybody worldwide. Libraries will mainly exist virtually, universities, institutions, departments and academics will have their own "online press" (open self-archives). There will be a change in the way knowledge is generated, disseminated, and absorbed. So hop on the train and 


\section{Stemmer et al., Electronic publishing}

hitch-hike PostGutenberg galaxy but do not forget to also remain a non-virtual "social" human being.

\section{References}

Bennett, S., 1999. Authors' Rights. The Journal of Electronic Publishing, Vol. 5, Issue 2, December 1999. $\leq$ http://www.press.umich.edu/jep/05-02/bennett.html $>$.

Bot, M., Burgemeester, J., \& Roes, H., 1998. The cost of publishing an electronic journal. D-Lib Magazine, November 1998. 〈http://www.dlib.org/dlib/november98/11roes.html>

Harnad, S., 1998a. For Whom the Gate Tolls? Free the Online-Only Refereed Literature. American Scientist Forum. 〈http://amsci-forum.amsci.org/archives/september98-forum.html > 〈http://www.cogsci.soton.ac.uk/ harnad/amlet.html>.

Harnad, S., 1998b. The invisible hand of peer review. Nature [online] (c. 5 Nov. 1998) http://helix.nature.com/webmatters/invisible/invisible.html.

Longer version: http://www.cogsci.soton.ac.uk/ harnad/nature2.html ftp://ftp.princeton.edu/pub/harnad/Harnad/HTML/nature2.html

Harnad, S. 1999a, The copyright non-problem and self-archiving. SEPTEMBER98-FORUM archives - 1999 〈http://amsci-forum.amsci.org/archives/september98-forum.html>.

Harnad, S. (1999b). Free at last: the future of peer-reviewed journals. D-Lib Magazine, Vol. 5, No. 12. 〈http://www.dlib.org/dlib/december99/12harnad.html]>

Odlyzko, A.M., 1998. The economics of electronic journals. In: Ekman R. and Quandt, R. (Eds) Technology and Scholarly Communication. Univ. Calif. Press, 1998. 〈http://www.research.att.com/ amo/doc/economics.journals.txt> 


\section{Stemmer et al., Electronic publishing}

Ransdell, J. M., 1999. The forgotten importance of editors. SEPTEMBER98-FORUM archives - 1999, 30 July 1999. <http://amsci-forum.amsci.org/archives/september98-forum.html>.

Relman, A., 1999. Editorial. The New England Journal of Medicine, Vol. 340, No. 23.

Sekikawa, A., Aaron D., Nishimura, R. Acosta, B., \& LaPorte, R., 1998. The metamorphosis of biomedical journals. British Medical Journal (article posted for on-line peer review, version September 11, 1998). 〈http://www.bmj.com/cgi/shtml/misc/peer/index.shtml $>$.

Walker, T. J., 1998. Free Internet access to traditional journals. American Scientist, 86 (5).

〈http://www.amsci.org/amsci/articles/98articles/walker.html>. 
TABLE 1. Examples for copyright and electronic posting policies, and paper and online subscription prices ${ }^{1}$

\begin{tabular}{|c|c|c|c|c|c|c|c|}
\hline Publisher & $\begin{array}{l}\text { Some journal ex- } \\
\text { amples }\end{array}$ & $\begin{array}{l}\text { Copyright } \\
\text { transfer } \\
\text { required? }\end{array}$ & $\begin{array}{l}\text { Electronic } \\
\text { posting al- } \\
\text { lowed? }\end{array}$ & $\begin{array}{l}\text { Institutional } \\
\text { subscription } \\
\text { price per year } \\
\text { in US } \$\end{array}$ & $\begin{array}{l}\text { Full online text } \\
\text { access included? }\end{array}$ & $\begin{array}{l}\text { Individual } \\
\text { subscription } \\
\text { price per } \\
\text { year in US \$ }\end{array}$ & $\begin{array}{l}\text { Full online } \\
\text { text access } \\
\text { included? }\end{array}$ \\
\hline $\begin{array}{l}\text { AAAS } \\
\text { www.sciencemag.org }\end{array}$ & Science $^{3}$ & yes & $\begin{array}{l}\text { no (pre-print } \\
\text { posting also } \\
\text { problematic) }\end{array}$ & $\begin{array}{l}\text { workstation } \\
\text { access: } 25 \$ x \\
\text { no. of work- } \\
\text { stations }\end{array}$ & $\begin{array}{l}\text { no (fees for site } \\
\text { licence or work- } \\
\text { stations) }\end{array}$ & $\begin{array}{l}200 \text { (AAAS } \\
\text { members) }\end{array}$ & $\begin{array}{l}\text { no (addi- } \\
\text { tional } 12 \$ \\
\text { per year) }\end{array}$ \\
\hline Academic Press & Brain and Language & yes & yes, if reader is & 899 & no (additional & information & NA \\
\hline $\begin{array}{l}\text { www.academicpress.c } \\
\text { om; } \\
\text { www.apnet.com/jour } \\
\text { nals/ }\end{array}$ & Brain and Cognition & yes & $\begin{array}{l}\text { alerted that the } \\
\text { copyright is re- } \\
\text { tained by AP } \\
\text { and a link to AP } \\
\text { is supplied }\end{array}$ & 545 & $\begin{array}{l}225 \$ / 136 \$ \text { per } \\
\text { year) } \\
\text { (special discount } \\
\text { rates available) }\end{array}$ & $\begin{array}{l}\text { on request } \\
\text { (not online or } \\
\text { in journal) }\end{array}$ & \\
\hline $\begin{array}{l}\text { APA } \\
\text { www.apa.org }\end{array}$ & $\begin{array}{l}\text { J. of Exp. Psychol- } \\
\text { ogy: Learning, } \\
\text { Memory and Cog- } \\
\text { nition }\end{array}$ & yes & no & 466 & no & $\begin{array}{l}244 \text { (non } \\
\text { member) }\end{array}$ & no \\
\hline $\begin{array}{l}\text { Cambridge University } \\
\text { Press } \\
\text { www.cup.cam.ac.uk } \\
\text { www.journals.cup.or } \\
\text { g/ }\end{array}$ & $\begin{array}{l}\text { BBS } \\
\text { (archive: } \\
\text { www.cogsci.soton } \\
\text {.ac.uk/bbs/ }\end{array}$ & yes & $\begin{array}{l}\text { submitted and } \\
\text { pre-print ver- } \\
\text { sions can be ar- } \\
\text { chived on BBS } \\
\text { server }\end{array}$ & $£ 249$ (UK) & $\begin{array}{l}\text { free access to pre- } \\
\text { prints (see archive } \\
\text { URL) }\end{array}$ & $£ 92(\mathrm{UK})$ & $\begin{array}{l}\text { free access to } \\
\text { pre-prints }\end{array}$ \\
\hline $\begin{array}{l}\text { Elsevier Science } \\
\text { www.elsevier.nl }\end{array}$ & $\begin{array}{l}\text { Trends in Neuro- } \\
\text { sciences }\end{array}$ & yes & NA & $\begin{array}{l}907 \\
\text { (print only) }\end{array}$ & $\begin{array}{l}\text { no; } 1225 \\
\text { (print \& online) }\end{array}$ & 147 & yes \\
\hline $\begin{array}{l}\text { Lawrence Erlbaum } \\
\text { www.erlbaum.com } \\
\end{array}$ & $\begin{array}{l}\text { Developmental } \\
\text { Neuropsychology }\end{array}$ & yes & NA & $\begin{array}{l}645 \\
580^{4} \\
\end{array}$ & yes & $95 / 85.50^{4}$ & yes \\
\hline $\begin{array}{l}\text { Lippincott Williams \& } \\
\text { Wilkins } \\
\text { www.lww.com } \\
\end{array}$ & $\begin{array}{l}\text { Neurology } \\
\text { www.neurology.org }\end{array}$ & yes & $\mathrm{NA}$ & 386 & yes & 273 & yes \\
\hline $\begin{array}{l}\text { Macmillan Publisher } \\
\text { www.nature.com }\end{array}$ & Nature & yes & $\begin{array}{l}\text { pre-print posting } \\
\text { allowed }\end{array}$ & $\begin{array}{l}\text { NA (new pol- } \\
\text { icy announced } \\
\text { for } 2000\end{array}$ & NA & 159 & yes \\
\hline Oxford University & Brain & yes & NA & $510 / 459^{4}$ & yes & 225 & yes \\
\hline
\end{tabular}




\begin{tabular}{|c|c|c|c|c|c|c|c|}
\hline \begin{tabular}{|l|} 
Press \\
www.oup.co.uk
\end{tabular} & $\begin{array}{l}\text { brain.oupjournals. } \\
\text { org/ }\end{array}$ & & & & & & \\
\hline $\begin{array}{l}\text { Swets \& Zeitlinger } \\
\text { www.szp.swets.nl }\end{array}$ & $\begin{array}{l}\text { J. of Clin. \& Exp. } \\
\text { Neuropsychology }\end{array}$ & yes & $\mathrm{NA}$ & 685 & 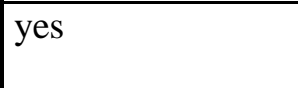 & 351 & no \\
\hline $\begin{array}{l}\text { Taylor \& Francis } \\
\text { www.tandf.co.uk }\end{array}$ & Aphasiology, & yes & NA & 1092 & yes & 460 & yes \\
\hline $\begin{array}{l}\text { The MIT Press } \\
\text { www.mitpress.com }\end{array}$ & $\begin{array}{l}\text { J. of Cogn. Neuro- } \\
\text { science }^{5}\end{array}$ & yes & NA & 275 & $\begin{array}{l}\text { yes (free also for } \\
\text { CogNet subscrib- } \\
\text { ers via HighWire } \\
\text { Press) } \\
\text { also for CogNet } \\
\text { subscrib }\end{array}$ & 80 & $\begin{array}{l}\text { yes (free also } \\
\text { for CogNet } \\
\text { subscribers) }\end{array}$ \\
\hline $\begin{array}{l}\text { Wiley-Liss } \\
\text { www.wiley.com }\end{array}$ & $\begin{array}{l}\text { Human Brain Map- } \\
\text { ping }\end{array}$ & yes & NA & 655 & no & 267 & no \\
\hline
\end{tabular}

${ }^{1}$ Information for this table was obtained either from the paper journal and/or from the online site of the publisher or journal. Due to space limitation, one journal per publisher relevant to the field was chosen as an example. Although a publisher often has the same or similar policies for most of its journals, a journal may have its individual policies. All prices and information were researched in March 2000. The prices refer to subscribers in North America unless otherwise indicated. For latest updates, the reader is advised to check for further details and online policies at the Website.

${ }^{2}$ If no explicit information concerning e-posting was provided in the paper journal or online this is marked by "NA", i.e. non applicable.

${ }^{3}$ Prices cited here are prices for AAAS members. Various, at times confusing, price models exist. 24-hours full access for $\$ 10$.

${ }^{4}$ Price for online-only subscription.

${ }^{5}$ Page charges for article submissions apply: \$ 40.00/page and a \$1,200.00/page charge for color plates. 